\title{
PENERAPAN ALJABAR PADA SISTEM PRODUKSI
}

\section{APPLICATION OF ALGEBRA IN PRODUCTION SYSTEMS}

\author{
Shinta Tri Kismanti' ${ }^{1}$, Desi Indriyani ${ }^{2}$ ) \\ 1)Program Studi Teknik Mesin, Fakultas Teknik, Universitas Borneo Tarakan \\ 2)Program Studi Matematika, Fakultas Pertanian, Universitas Abdurachman Saleh Situbondo \\ Email: kismanti88@gmail.com ${ }^{1)}$, desi.indriyani@unars.ac.id ${ }^{2)}$
}

\begin{abstract}
ABSTRAK
Penggunaan aljabar max-plus diantaranya pada proses produksi perakitan. Dalam konteks aljabar max-plus sistem model yang terjadi adalah linier dan non-linier pada aljabar biasa, kelinieran ini tentunya akan memudahkan dalam penganalisaan sistem yang dikaji. Selanjutnya diberikan suatu asumsi yang realistik untuk mendapatkan suatu jadual yang reguler (teratur) dari sistem yang dikaji kemudian dilakukan simulasi dari sistem yang diberikan lewat keadaannya dengan menggunakan Petri Net. Petri Net merupakan suatu alat bantu untuk mempelajari system.
\end{abstract}

\section{Kata Kunci: aljabar, petri net, proses produksi}

\section{ABSTRACT}

The use of max-plus algebra includes in the assembly production process. In the context of max-plus algebra the model system that occurs is linear and non-linear in ordinary algebra, this linearity will certainly facilitate the analysis of the system under study. Furthermore, a realistic assumption is given to obtain a regular schedule of the system being studied, then a simulation of the given system is carried out using Petri Net. Petri Net is a tool for studying the system.

Keywords: algebra, petri net, production process

\section{PENDAHULUAN}

Aljabar merupakan cabang ilmu matematika yang mempelajari konsep atau prinsip penyederhanaan serta pemecahan masalah dengan menggunakan symbol atau huruf tertentu. Salah satu ruang lingkup dalam aljabar yaitu aljabar max-plus. Aljabar max-plus dapat digunakan untuk menggambarkan secara linier dinamika waktu dari suatu system non linier dalam aljabar konvensional. Pendekatan aljabar max-plus berguna untuk menentukan dan menganalisis kejadian diskrit. System kejadian diskrit selalu dipengaruhi oleh waktu. Setiap waktu bertambah pasti keadaan system akan bertambah pula (Subiono, 2004).

Aljabar Max-Plus juga dapat diaplikasikan untuk mengkonstruksi bentuk umum model sistem produksi dengan atau tanpa buffer. Aljabar MaxPlus juga digunakan pada penjadwalan flowshop dengan menggunakan model timed petri net dengan tujuan menghasilkan desain penjadwalan job pada sistem produksi flowshop tiga job pada lima mesin sehingga menghasilkan makespan yang minimum (Indriyani, 2016). 
JURNAL BORNEO SAINTEK

Volume 4, Nomor 1, April 2021

e-ISSN 2599-3313

P-ISSN 2615-434X

Penjadwalan

merupakan

pengkoordinasian tentang waktu dalam kegiatan berproduksi, sehingga dapat diadakan pengalokasian bahan-bahan baku dan bahan-bahan pembantu, serta perlengkapan kepada fasilitas-fasilitas atau bagianbagian pengolahan dalam pabrik pada waktu yang telah ditentukan (Assauri, 1993). Masalah-masalah yang sering dihadapi dalam penjadwalan diantaranya dikarenakan banyaknya mesin, banyaknya pekerjaan, urutan dan waktu operasi yang berbeda pada setiap pekerjaan (Harding, 1984). Perhitungan penjadwalan sangat memperhitungkan dari kuantitas atau banyaknya mesin yang digunakan sebagai alat produksi sehingga diperlukan ketelitian ekstra.

Hal tersebut akan menjadi lebih rumit jika terdapat mesin yang rusak ketika akan dilakukan produksi hal ini akan menyebabkan dilakukanya tindakan penjadwalan ulang. Selain itu, jika terdapat kesalahan dalam menganalisa waktu operasi yang berbeda-beda pada setiap produk maka akan menyebabkan penjadwalan produksi menjadi kacau.

Dengan demikian, ketelitian dalam menganalisis waktu operasi merupakan hal paling penting karena tujuan dasar dari penjadwalan adalah untuk mengefisiensikan waktu sehingga dapat memenuhi permintaan pasar. Metode penjadwalan yang digunakan dalam penelitian ini adalah aljabar Max-Plus. Aljabar Max-Plus digunakan karena kemudahannya dalam menyelesaikan proses sinkronisasi dan untuk mengoptimasi jadwal produksi sehingga waktu produksi dapat digunakan secara efektif dan efisien.

Petri Net merupakan suatu alat bantu untuk mempelajari system. dengan menggunakan teori Petri Net, maka suatu system dapat dimodelkan menjadi suatu jaringan petri yang merupakan representasi matematika dari system tersebut. Dengan melakukan analisis dari
Available online at www.jurnal.borneo.ac.id Halaman 37-42

jaringan petri tersebut diharapkan akan dipeproleh informasi penting tentang struktur dan perilaku yang dinamis dari sitem yang dimodelkan dan mengusulkan peningkatan-peningkatan serta perubahan-perubahan yang diperlukan.

\section{METODE PENELITIAN}

\section{a. Aljabar Max-Plus}

Aljabar Max-Plus merupakan perluasan dari Aljabar Linier biasa, dengan operasi maksimum dan tambah. Diberikan $\mathbb{R}_{\varepsilon} \stackrel{\text { def }}{=} \mathbb{R} \cup\{\varepsilon\}$ dengan $\mathbb{R}$ adalah himpunan semua bilangan real dan $\varepsilon \stackrel{\text { def }}{=}$ $-\infty$. Pada $\mathbb{R}_{\varepsilon}$ didefinisikan operasi berikut: $\forall x, y \in \mathbb{R}_{\varepsilon}, x \oplus y \stackrel{\text { def }}{=} \max \{x, y\}$ dan $x \otimes y \stackrel{\text { def }}{=} x+y$. Subiono (2015). Selanjutnya, $\quad\left(\mathbb{R}_{\varepsilon}, \oplus, \otimes\right) \quad$ merupakan semiring dengan elemen netral $\varepsilon$ dan elemen satuan $e=0$. Untuk selanjutnya $\left(\mathbb{R}_{\varepsilon}, \oplus, \otimes\right)$ akan ditulis $\mathbb{R}_{\max }$.

Definisi misalkan $R_{-} \varepsilon=R \cup\{\varepsilon=-\infty\}$ dan pada $\mathbb{R}_{\varepsilon}$ didefinisikan dua operasi biner:

(i) $a \oplus \mathrm{b}=\operatorname{maks}\{a, b\} \quad$ dibaca $\mathrm{O}$ tambah

(ii) $a \otimes b=a+b$ dibaca 0 kali $\forall a, b \in \mathbb{R}_{\varepsilon}, \mathbb{R}_{\varepsilon}$ dengan dua operasi biner di atas disebut aljabar max-plus yang dinotasikan dengan $\mathbb{R}_{\max }$

Pangkat dalam Aljabar Max-Plus secara biasa diperkenalkan dengan menggunakan sifat asosiatif. Untuk $x \in$ $\mathbb{R}_{\text {max }}$ dan untuk semua $n \in \mathbb{N}$, dengan $\mathbb{N}$ adalah bilangan asli dan $n \neq 0$ didefinisikan:

$$
x \otimes n \stackrel{\text { def }}{=} \underbrace{x \otimes x \otimes \ldots \otimes x}_{n}
$$

sedangkan untuk $n=0$ didefinikan $x^{\otimes n} \stackrel{\text { def }}{=}$ $e$, dengan $e=0$ dan dalam aljabar biasa dapat ditulis sebagai berikut (Subiono, 2015):

$$
x \otimes n \stackrel{\text { def }}{=} \underbrace{x \otimes x \otimes \ldots \otimes x}_{n}=n \times x
$$

Berdasarkan definisi dua operasi biner pada di atas, maka berlaku sifat-sifat berikut:

i) $\left(\mathbb{R}_{\varepsilon}, \oplus\right)$ memiliki sifat:

- Tertutup, $a \oplus b \in \mathbb{R}_{\varepsilon}$ 
JURNAL BORNEO SAINTEK

Volume 4, Nomor 1, April 2021

e-ISSN 2599-3313

P-ISSN 2615-434X

- Komutatif, $a \oplus b=b \oplus a$

- Asosiatif, $a \oplus(b \oplus c)=(a \oplus$ b) $\oplus c$

- Memiliki unsur Identitas, $a \oplus$ $\varepsilon=\varepsilon \oplus a=a$

ii) $\left(\mathbb{R}_{\varepsilon}, \otimes\right)$ memiliki sifat :

- Tertutup, $a \otimes b \in \mathbb{R}_{\varepsilon}$

- Komutatif, $a \otimes b=b \otimes a$

- Asosiatif, $a \otimes(b \otimes c)=(a \otimes$ b) $\otimes c$

- Memiliki unsur Identitas, $a \otimes$ $0=0 \otimes a=a$. Selanjutnya 0 dinotasikan dengan $e$

iii) Distributif $\otimes$ terhadap $\oplus: a \otimes(b \oplus$ $c)=(a \otimes b) \oplus(a \otimes c)$
Available online at www.jurnal.borneo.ac.id Halaman 37-42

$$
\mathbb{R}_{\text {max }}^{n}=\mathbb{R}_{\varepsilon} \times \mathbb{R}_{\varepsilon} \times \ldots \times \mathbb{R}_{\varepsilon}=\left\{\vec{a}=\left(a_{1}, a_{2}, \ldots, a_{n}\right) \mid a_{i} \in \mathbb{R}_{\varepsilon}, i=1, \ldots, n\right\} \text { dan pada } \mathbb{R}_{\text {max }}^{n}
$$

didefinisikan operasi:

i) $\oplus: \vec{a} \oplus \vec{b}=\left(a_{1}, a_{2}, \ldots, a_{n}\right) \oplus\left(b_{1}, b_{2}, \ldots, b_{n}\right)$

ii) $\otimes$ dengan scalar $a$ di $\mathbb{R}_{\varepsilon}$ $a \otimes \vec{a}=a \otimes\left(a_{1}, a_{2}, \ldots, a_{n}\right)=$ $=\left(a \otimes a_{1}, a \otimes a_{2}, \ldots, a \otimes a_{n}\right)$

$\vec{a} \in \mathbb{R}_{\text {max }}^{n}$ disebut vektor pada aljabar maxplus. Vektor nol di $\mathbb{R}_{\max }^{n}$ dinotasikan dengan $\vec{\varepsilon}$ dan didefinisikan sebagai vektor $\vec{\varepsilon}=(\varepsilon, \varepsilon, \ldots, \varepsilon)$

Berikut ini didefinisikan operasi matriks pada aljabar max - plus

\section{Definisi}

i) Untuk $A, B \in \mathbb{R}_{\max }^{m \times n}$, maka $A \oplus B=\left[a_{i j} \oplus b_{i j}\right] \operatorname{dimana} A \oplus B \in \mathbb{R}_{\max }^{m \times n}$

ii) Untuk $A \in \mathbb{R}_{\max }^{m \times p}$ dan $B \in \mathbb{R}_{\max }^{p \times n}$, maka $A \otimes B=C$ dimana $C \in \mathbb{R}_{\max }^{m \times n}$ dan $c_{i j}=$ $\bigoplus_{k=1}^{p} a_{i k} \otimes b_{k j}$

Untuk $i=1,2, \ldots, m$ dan $j=1,2, \ldots, n$

iii) Untuk sembarang Matriks $A \in \mathbb{R}_{\max }^{m \times n}$ dan sebarang skalar $a \in \mathbb{R}_{\max }$ maka $a \otimes A=a \otimes\left[a_{i j}\right]=\left[a \otimes a_{i j}\right] \quad$ dimana $a \otimes A \in \mathbb{R}_{\max }^{m \times n}$

\section{b. Petri Net}

Petri Net pertama kali dikembangkan oleh C.A. petri pada awal tahun 1962 iv) Untuk setiap $a \in \mathbb{R}_{\varepsilon}$ dengan $\neq \varepsilon$, terdapat $c$ tunggal elemen $\mathbb{R}_{\varepsilon}$ dan bersifat $a \otimes c=e, c$ dinamakan unsur balikan dari terhadap operasi $\otimes$.

Setelah definisi aljabar max-plus selanjutnya akan dibahas vektor dan matriks pada aljabar max-plus. Seperti pada vektor dan matriks real yang elemen-elemennya himpunan bilangan real, vektor dan matriks pada aljabar max-plus merupakan vektor dan matriks yang elemen-elemennya di $\mathbb{R}_{\max }$. Berikut ini akan didefinisikan $\mathbb{R}_{\text {max }}^{n}$, berdasarkan $\mathbb{R}_{\text {max }}$ sebagai:
(Freya, dkk, 2012). Petri Net merupakan suatu alat bantu untuk memodelkan system event discrete yang menggambarkan hubungan antara kondisi dan peristiwa. System event discrete merupakan sistem dengan ruang keadaan yang diuraikan secara diskrit $\{0,1,2, \ldots\}$ dan transisi keadaan hanya diamati pada titik diskrit dalam waktu. Dengan demikian, pada system event discrete keadaan berubah disebabkan oleh adanya event (Cassandras, 1993).

Petri Net merupakan direct bipartite graph (graf berarah) dengan dua node, yaitu place (simbol lingkaran) dan transisi (simbol persegi panjang). Arc yang menghubungkan place dan transisi disimbolkan dengan anak panah. Setiap place berisi satu atau beberapa token yang dilambangkan dengan dots atau bulatan kecil. Token merupakan material atau bahan baku yang ditransfer dalam satu sistem Petri Net.

\section{Definisi 1:}

Petri Net terdiri dari 4-tuple $(P, T, A, w)$ dengan:

$P$ : himpunan berhingga Place, $P=$ $\left\{p_{1}, p_{2}, \ldots, p_{n}\right\}$

$T$ : himpunan berhingga transisi, $T=$ $\left\{t_{1}, t_{2}, \ldots, t_{n}\right\}$ 
$A$ : himpunan arc, $A \subseteq(P \times T) \cup(T \times P)$

$w:$ fungsi bobot, $w: A \rightarrow\{1,2,3, \ldots\}$

(Cassandras, 1993)

Dalam merepresentasikan Petri Net maka digunakan notasi $I\left(t_{j}\right)$ untuk input dan $O\left(t_{j}\right)$ untuk output yang secara sistematis dapat ditulis dengan persamaan berikut.

$$
\begin{aligned}
& I\left(t_{j}\right)=\left\{p_{i}:\left(p_{i}, t_{j}\right) \in A\right\} \\
& O\left(t_{j}\right)=\left\{p_{i}:\left(t_{j}, p_{i}\right) \in A\right\}
\end{aligned}
$$

\section{c. Sistem Produksi}

Gaspersz (1988) mengatakan bahwa konsep dasar sistem produksi terdiri dari elemen input, proses, dan elemen output dalam sistem produksi. Elemen input dalam sistem produksi dibagi menjadi dua, yaitu input tetap yang dalam penggunaannya tidak bergantung pada jumlah output yang akan diproduksi dan input variabel yang merupakan kebalikan dari input tetap. Input tetap dapat berupa tenaga kerja, energi, informasi, dan manajerial. Sedangkan input variabel dapat berupa modal, bahan baku, dan energi. Input merupakan masukan agar dapat terjadi proses produksi untuk memperoleh output dengan harapan nilai yang lebih tinggi.

Dalam sistem produksi, sangat penting untuk merencanakan manajemen dan penggunaan resource (faktor-faktor produksi) agar proses berjalan lancar dan menghasilkan output yang sesuai dengan tujuan (Nasution, 2003). Selain itu, juga perlu memperhatikan faktor internal dan ekternal dalam merencanakan suatu produksi.

\section{d. Aljabar Max-plus pada Sistem Produksi Sederhana}

Dipilihnya simbol $\oplus$ dan $\otimes$ dalam aljabar max-plus adalah ada analogi diantara $\oplus$ dengan + dan $\otimes$ dengan $x$. Dengan menggunakan simbol-simbol tsb. diskripsi ruang keadaan sistem dapat ditulis dalam bentuk:

$$
\begin{aligned}
x(k+1)= & A \otimes x(k) \oplus B \otimes u(k) \ldots \ldots \ldots \ldots(1) \\
& y(k)=\quad C \otimes x(k) \ldots \ldots \ldots \ldots(2)
\end{aligned}
$$

Dengan:

- $\mathrm{u}(\mathrm{k})$ adalah waktu dimana bahan baku dimasukkan ke sistem untuk saat ke- $(\mathrm{k}+1)$;

- $x_{i}(k)$ adalah waktu dimana sistem ke(i) mulai memproduksi saat ke-k, dengan $\mathrm{i}=1,2$, 3;

- $y(k)$ adalah waktu dimana produk selesai pada saat ke-k meninggalkan sitem (ditawarkan ke dunia luar/ konsumen).

Pengertian nilai-eigen dan vektoreigen yang bersesuaian dari suatu matriks bujur sangkar sebagaimana dijumpai dalam aljabar linier biasa juga dijumpai dalam aljabar max-plus, yaitu bila dipunyai persamaan:

$$
A \otimes x=\lambda \otimes x
$$

dalam hal ini masing-masing vektor $x$ dan $\lambda$ dinamakan vektor eigen dan nilai eigen dari matriks $A$. Pada sistem produksi sederhana, vektor dan nilai eigen dapat digunakan sebagai penentuan suatu keadaan awal dari sistem supaya memperoleh evolusi suatu keadaan sistem periodik. Suatu algoritma untuk memperoleh vektor eigen dan nilai eigen dari matriks bujur sangkar.

\section{HASIL DAN PEMBAHASAN}

Sistem produksi merupakan suatu kesatuan proses kompleks yang tidak dapat dipisahkan dalam menghasilkan suatu produk. Dikarenakan merupakan kesatuan yang kompleks, maka dalam proses menghasilkan produk sering ditemukan berbagai macam permasalahan. Permasalahan atau 
kendala yang ditemukan dapat berasal dari luar maupun dari dalam proses produksi itu sendiri. Kendala yang berasal dari luar dapat berupa faktor penghambat sebelum proses produksi dimulai, seperti keterlambatan penyediaan bahan dasar produksi. Sedangkan faktor penghambat dari dalam proses produksi itu sendiri berupa kapasitas mesin produksi ataupun jadwal produksi yang tidak optimal sehingga tidak tepat waktu dalam menghasilkan produk yang dimaksud.

Permasalahan yang timbul dari dalam proses produksi ini yang banyak diteliti untuk dicari penyelesaiannya. Salah satu metode yang digunakan adalah dengan menggunakan Petri Net dan Aljabar MaxPlus. Petri Net digunakan untuk merepresentasikan alur proses produksi untuk mempermudah dalam memahami urutan proses produksi itu sendiri. Petri Net terdiri dari place dan transisi, dengan place sebagai input atau output pada suatu transisi. Place input harus dipenuhi agar transisi dapat terjadi sehingga keadaan dapat berubah. Jumlah place dipengaruhi oleh banyaknya langkah yang harus dilalui, dimulai dari bahan dasar sebagai inputan awal hingga menjadi produk yang dimaksud. Sedangkan jumlah transisi ditentukan dari banyaknya kejadian dari place yang satu ke place yang lain. Dengan petri net dapat dilakukan simulasi proses produksi sehingga urutan proses produksi yang dimaksud dapat dipahami lebih mudah.

Setelah memperoleh alur produksi yang benar melalui representasi petri net, selanjutnya dibuat model matematika dengan Aljabar Max-Plus. Namun, sebelum membuat model aljabar Max-Plus harus didefinisikan variabelvariabel yang digunakan dalam model Petri Net. Dari model aljabar Max-Plus tersebut dilakukan analisis untuk memperoleh jadwal produksi yang optimal sesuai target yang telah ditentukan.

Petri Net dan Aljabar Max-Plus juga dapat digunakan untuk menyelesaikan permasalahan rantai pasok. Rantai pasok pada sistem produksi disimulasikan dengan Petri Net untuk kemudian dimodelkan menggunakan Aljabar MaxPlus untuk mengetahui kinerja dari rantai pasok. Berdasarkan model Petri Net dan Aljabar Max-Plus pada rantai pasok sistem produksi juga dapat diketahui lamanya waktu proses pendistribusian dan produksi dari bahan baku serta kemasan hingga diterima konsumen. Hasil lamanya waktu tersebut dapat dipakai untuk mengatur rantai pasok sistem produksi agar tidak terjadi overload sehingga dapat meminimalisir biaya produksi.

Untuk membuat sebuah manajeman sistem produksi diperlukan adanya urutan pengelolaan didalamnya. Dimana dalam urutan pengelolaan tersebut harus diketahui gambaran sesungguhnya dan lengkap yang memperlihatkan keseluruhan yang ada, dimulai dari awal pengelolaan hingga akhir.

Input bahan baku dan kemasan terdapat buffer dengan kapasitas yang cukup besar untuk menjamin bahwa buffer tidak akan pernah overflow. Suatu unit pemroses hanya bisa mulai bekerja untuk melanjutkan tahap berikutnya jika telah menyelesaikan proses sebelumnya. Diasumsikan juga bahwa setiap unit pemroses sesegera mungkin mulai bekerja bila semua komponen pendukung telah tersedia.

Sistem produksi yang telah disimulasikan dengan petri net akan dimodelkan menggunakan aljabar maxplus untuk mengetahui kinerja dari pada sistem produksi, yaitu mengetahui lama waktu dan waktu berakhirnya proses produksi. 
JURNAL BORNEO SAINTEK

Volume 4, Nomor 1, April 2021

e-ISSN 2599-3313

P-ISSN 2615-434X

\section{KESIMPULAN}

Sistem produksi merupakan serangkaian produksi, dimulai dengan menginputkan bahan baku hingga menghasilkan suatu produk yang tidak jarang mengalami permasalahan dalam prosesnya. Petri Net dan Aljabar Max-Plus merupakan metode yang dapat dipilih untuk menyelesaikan permasalahan dalam sistem produksi, terutama mengenai jadwal pendistribusian dan produksi. Dengan penjadwalan yang baik dalam produksi, maka dapat meminimalkan biaya produksi. Selain itu, produsen juga akan mendapatkan penilaian yang bagus dari konsumen karena produk dapat sampai tepat waktu.

\section{DAFTAR PUSTAKA}

Nasution. 2002. Metode Penelitian Naturalistik Kualitatif. Bandung: Tarsito.

Sukanto, Reksohadiprojo dan Indriyo, Gitosudarmo. 1988. Manajemen Produksi Edisi 4. Yogyakarta: BPFE UGM.

Subiono. 2015. Aljabar Min-Max Plus dan Terapannya. Surabaya: Institut Teknologi Sepuluh Nopember.

Gaspersz, V. 1988. Production Planning and Inventory Control. Jakarta: Gramedia Pustaka Utama.

Cassandras, C.G. 1993. Discret Event System: Modelling and Performance Analysis, Aksen Assosiates Incorporate Publisher, Boston.

Pramesthi, Sri Rejeki Puri Wahyu. 2021. Simulasi Petri Net pada Proses Produksi Susu Fermentasi. Jurnal Pendidikan Matematika dan Matematika: vol. 3 (1) Februari 2021 pp. 25-36.

Nurmalitasari, Dewi dan Iswahyudi, Ratna Eka. 2019. Desain Petri Net dan Aplikasi Max-Plus pada Produksi Susu Kedelai Berkah. Prosiding Seminar Nasional Integrasi Matematika dan Nilai
Available online at www.jurnal.borneo.ac.id Halaman 37-42

Islami: vol. 3 No. 1, September 2019, hlm. 268-276.

Bintoto, Pohet. 2016. Aplikasi Aljabar Max-Plus pada Sistem Produksi Tipe Assembly. Prosiding Seminar Nasional Pendidikan Matematika 2016 volume 1 Tahun 2016-ISSN 2528-259X.

Singgih, Moses dan Nurlina, Nila. 2014. Alokasi Resource sebagai Perbaikan Produksi Menggunakan Holonic Manufacturing System, Petri Net, dan Aljabar Max-Plus. Seminar Nasional Teknik Industri BKSTI 2014.

Afif, Ahmad dan Mustofani, Dian. 2018. Model Rantai Pasok pada Sistem Produksi Menggunakan Petri Net dan Aljabar Max-Plus. Jurnal UJMC, Volume 05, Nomor 01.

Assauri, Sofjan. 1993. Manajemen Produksi dan Operasi. Jakarta : Lembaga Penerbit Fakultas Ekonomi Universitas Indonesia.

Fauzi dan Adzkiya. 2016. Peneraman Model Predective Control (MPC) pada Flow Line Sistem Produksi Menggunakan Aljabar Max-Plus. Jurusan Matematika, Fakultas Matematika dan Ilmu Pengetahuan Alam, Institut Teknologi Sepuluh Nopember, Surabaya.

Indriyani, Subiono. 2016. Scheduling of The Crystal Sugar Production System in Sugar Factory Using Max-Plus Algebra. INTERNATIONAL JOURNAL OF COMPUTING SCIENCE AND APPLIED MATHEMATICS. VOL. 2, NO. 3, SEPTEMBER 2016, 33-27.

Subiono. 2004. Terapan Aljabar Max-Plus Pada Sistem Produksi Sederhana Serta Simulasinya Dengan Menggunakan Matlab. . Journal of Mathematics and Its Applications. Vol. 1, No. 2, November 2004, 17. 
